\title{
Cutaneous Horn on Four-year-old Child's Arm: A Quiz
}

Cassandre POTTIER ${ }^{1,2}$, Annabel MARUANI ${ }^{1,2}$, Fanny DUJARDIN ${ }^{3}$ and Juliette ROBERT ${ }^{2}$

${ }^{1}$ University of Tours, ${ }^{2}$ Department of Dermatology, Unit of Paediatric Dermatology, and ${ }^{3}$ Department of Pathology, Centre Hospitalier Régional Universitaire de Tours, Tours, France. Email: cassandre.pottier@gmail.com

A 4-year-old girl with a history of atopic dermatitis was referred to our hospital for a tumour in the elbow flexor crease of the left arm. Her parents first noticed a papule 4 months earlier that grew progressively. She received oral and topical antibiotics, with no success.

Clinical examination revealed a yellow-brown hyperkeratotic horn (Fig. 1a) arising from a well-defined erythematous base (Fig. 1b). An underlying subcutaneous nodule was palpable. The rest of the clinical examination was normal. The tumour size was approximately $4 \times 5 \times 8 \mathrm{~mm}$.

The lesion was surgically removed. Macroscopic examination revealed a chalky white material when the tumour broke into 2 pieces during the procedure. The histopathology of the 2 fragments of the tumour is shown in Fig. 1c and $\mathrm{d}$.

What is your diagnosis? See next page for answer.

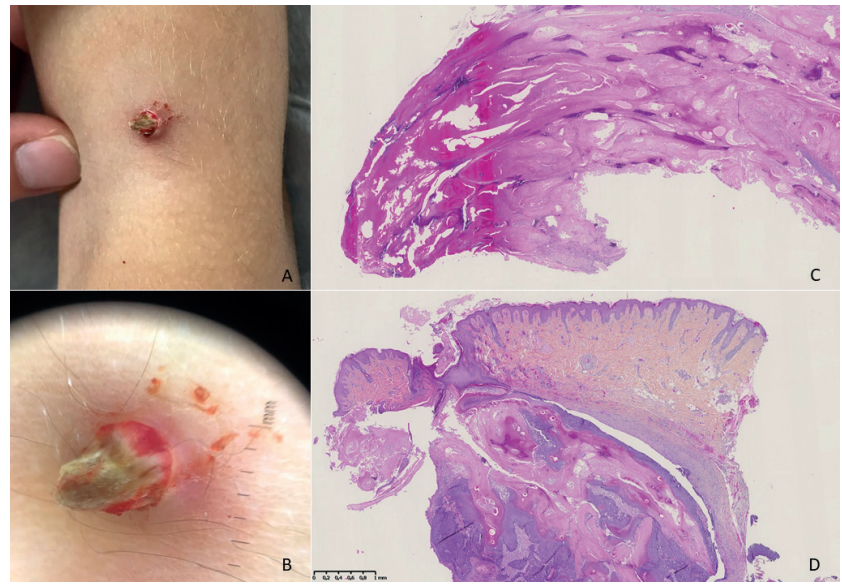

Fig. 1. (a) Indurated tumour with a well-defined erythematous base, topped with a hyperkeratotic crust on the left arm of a 4-year-old girl. (b) Dermoscopy of the tumour; (c) Microscopy (original magnification $\times 2$ ) with haematoxylin-eosin staining, showing a panoramic view of the distal part of the tumour, consisting of non-viable mummified matrix cells (horn); (d) Microscopy (original magnification $\times 2$ ) with haematoxylin-eosin staining showing the proximal part of the tumour, consisting of a mixture of darkly stained "basophilic" cells and "ghost" cells with missing nuclei (base). 


\section{ANSWERS TO QUIZ}

\section{Cutaneous Horn on Four-year-old Child's Arm: A Commentary}

Acta Derm Venereol 2021; 101: adv00567.

\section{Diagnosis: Pilomatricoma}

Histology revealed a large nodular lesion located in the deep dermis and, mostly, in the hypodermis, with trabeculae of matrical cells, which mature to produce superficial cornified cells with ghostlike nuclear outlines and focal areas of calcification. The dermic nodule was a mixture of darkly stained "basophilic" cells and "ghost" cells with missing nuclei (Fig. 1d), which is typical of pilomatricoma. The horn consisted only of non-viable mummified matrix cells (Fig. 1c).

Pilomatricoma, also known as pilomatrixoma, or calcifying epithelioma of Malherbe, is a benign tumour, which develops from the matrix cells of hair follicles, located in the deep dermis or subcutaneous layer. Pilomatricoma is most commonly observed in children and has a female predominance. It usually presents as a firm or stone-hard solitary nodule or indurated tumour. The elective localizations are the head, neck or extremities $(1,2)$. Multiple pilomatricomas can rarely reveal Steinert myotonic dystrophy $(1,2)$. Pilomatricomas usually grow slowly for a few years and do not show spontaneous regression. The treatment of choice is surgical excision. Recurrences can be observed in rare cases of incomplete removal.

We describe here a variant of pilomatricoma associated with a cutaneous horn. To our knowledge, these types of pilomatricomas have been described only a few times (3-6), including one case located on the arm of an 11-year-old girl (3). These types of pilomatricomas might be a variant of perforating pilomatricoma with mummified tumour cells perforating the epidermis via transepidermal elimination (7), which could be an attempt to extrude the tumour.

Differential diagnoses of cutaneous horn in a child include molluscum contagiosum, verruca vulgaris, pyogenic granuloma and juvenile xanthogranuloma. In an adult, a differential diagnosis would be cutaneous squamous cell carcinoma.

The authors have no conflicts of interest to declare

\section{REFERENCES}

1. Hu JL, Yoo H, Kwon ST, Kim S, Chung JH, Kim H, et al. Clinical analysis and review of literature on pilomatrixoma in pediatric patients. Arch Craniofac Surg 2020; 21: 288-293.

2. Laffargue JA, Stefano PC, Vivoda JL, Yarza ML, Belleli AG, Castro $M N$, et al. Pilomatrixomas in children: report of 149 cases. A retrospective study at two children's hospitals. Arch Argent Pediatr 2019; 117: 340-343.

3. Kost DM, Smart DR, Jones WB, Bain M. A perforating pilomatricomal horn on the arm of an 11-year-old girl. Dermatol Online J 2014; 20: 22371.

4. Leblebici C, Yeni B, Erdem O, Aksu AEK, Bozkurt ER, Demirkesen C. Superficial variant of pilomatricoma, so-called pilomatricomal horn. J Cutan Pathol 2019; 46: 801-804.

5. Uchiyama N, Shindo Y, Saida T. Perforating pilomatricoma. J Cutan Pathol 1986; 13: 312-318.

6. Garcia de la Torre JP, Saiz A, Garcia-Arpa M, RodriguezPeralto JL. Pilomatricomal horn: a new superficial variant of pilomatricoma. Am J Dermatopathol 2006; 28: 426-428.

7. Arnold M, McGuire LJ. Perforating pilomatricoma - difficulty in diagnosis. J Am Acad Dermatol 1988; 18: 754-755. 